\title{
Assessment of grain loss due to insect pest during storage for small-scale farmers of Kebbi
}

\author{
Iliyasu Mohammed Utono \\ (College of Agriculture P.M.B 1018, Zuru, Nigeria;
}

\begin{abstract}
Grain storage losses due to insect pests have been a serious problem threatens the livelihood of small-scale farmers. Sampling and inspection of grain stores provide important information that is useful in identifying and managing insects problems associated with grain storage. A survey of sampling farmers' grain stores was conducted in three geo-political regions (Central, North and South) of Kebbi state to gain a better understanding of the insect pest species and the impending associated problems they cause in farmers grain stores, and to help farmers with new approach (VDS) for assessing grain damage by themselves and compare the precision of the new approach with conventional approach in assessing grain weight loss. The findings of this research indicate that the VDS method is comparable $\left(r^{2}=0.76 ; t=14.19, d f=147, p<0.001\right)$ with conventional method of assessing weight loss and can be used as a rapid method of assessing the degree of damage to grain and proportional loss for sorghum, millet and threshed maize. The most commonly found insect was $T$. castaneum, followed by $R$. dominica. Sorghum significantly $\left(\chi^{2}=230.62, d f=12, p<0.003\right)$.had the highest mean number of insect species, and the highest number of insects of each species, mainly T. castaneum $(10.1 \pm 0.83)$ than found in millet $(4.0 \pm 0.78)$, and maize $(7.9 \pm 0.78)$. Threshed sorghum stored in storerooms in the south significantly suffered most weigh loss than all other types of grain stored in both granaries and storerooms in all regions. This study highlights the groups most in need of help with insect control.
\end{abstract}

Key words: Insects, Region, Threshed grain, Weight loss, Visual damage scale

\section{Introduction}

Storage losses due to insect pest infestations have been a problem of major concern among smallholder farmers who use traditional storage structures [1]; [2]. Inspection, sampling and monitoring of grain stores provide baseline information that is useful in identifying and managing problems associated with grain storage, particularly insect pest infestations. Information generated from these techniques can be useful in evaluating the relative importance of loss-causing factors such as temperature, moisture content of grains the presence of insect pest species and the effect of storage structures. Damage to stored grain is easier to categorise by visual observation of the relative amount of damage to the grain and by measuring the amount of weight loss [3].

At a local farmer level, farmers judge damage and losses to their grain stores by visual observation of the condition of their grain. Thus, development of simple and standardised methods of loss assessment that is rapid and can be easily understood and conducted by farmers is important. Farmers need to be able to identify and understand grain damage in their store and estimate of the likely economic value associated with each level of grain damage. Understanding this damaged-economic value link could help farmers to better understand what quality of grain is required by the market in order to improve their income. The visual damage scale (VDS) method, whereby farmers are asked to assess the status of their grain against an annotated photograph of typical loss categories (described in more detail below) has been found to be simple, rapid, easy to work with and relatively standardized, producing outcomes similar to the more conventional 'count and weigh' weight loss method [4]. The VDS method has already been established for maize cobs [4] and pearl millet [5], but not sorghum, threshed maize or un-threshed millet. Therefore, for this study, new visual damage scale (VDS) charts were produced for these grains, as described below, with aim to:

* Established a rapid method of assessing the degree of damage to grain and proportional loss for sorghum, millet and threshed maize.

* Use the VDS to help farmers gain an understanding of the process and importance of grain damage assessment through participatory research, so that they can classify degree of grain damage and loss for themselves.

* To compare the precision of the VDS assessment method with the conventional weight loss method.

* To obtain baseline data on the insect pest species and associated weight loss they cause in stored grain amongst farmers in Kebbi

* To identify the target farmers groups most in need of help with insect control. 


\section{Materials And Methods \\ 2.1 Study area and grain stores sampling}

This study was conducted in the three geo-political regions (Central, North and South) of Kebbi state. Samples of grain were collected from 150 farmers' stores ( 50 for each region) storing either sorghum, millet or maize (at least 15 stores for each type of grain) during storage season in a single visit to determine the insect pest species present and to estimate the degree of damage and the proportional weight loss due to insect pests. The store samples were obtained from the stores of at least five out of ten farmers presented by the village extension agent in each of eight villages for each region. The sampling was done the same way in all the stores of farmers chosen.

\subsection{Estimating the proportion of grain loss due to damage caused by insects Sampling grain in stores}

The percentage damage caused by the insect pest species present here were estimated from samples of grain collected from the farmers' stores, using $50 \mathrm{~cm}$, and $1 \mathrm{~m}$ compartmentalized sample spears. The $50 \mathrm{~cm}$ spear was used to collect $1 \mathrm{~kg}$ samples from grain stored in bags and weight loss was calculated from $100 \mathrm{~g}$ subsample by the 'count and weigh' method [6]. The spear was effectively a long tube, with one side of the tube cut away, so that as the spear is pulled out of the bag, if the opening faces downward the grain in the tube will fall into the collecting container.

The $1 \mathrm{~m}$ compartmentalized sample spear was used to collect grain samples stored in mass from granaries and rooms. Each sample was taken by inserting the spear into the grain mass straight to the maximum depth, and then rotating the inner tube to ensure that the open compartments filled up with grain, and then rotated back to close the compartments. The spear samples were emptied, on a cloth spread on the ground. An assessment of each pile of grain was done by visual analysis. Five samples were taken using the $1 \mathrm{~m}$ spear from different portions of the stored grain mass. The samples were pooled for final assessment and measuring weight loss.

\section{Developing a visual damage scale (VDS) for Kebbi region}

To help farmers learn how to assess losses in their stored grain themselves, a rapid loss assessment method [7] (Compton et al., 1998; [4] was used. This method involve using a standardize visual damage scale (VDS) which was developed for this research following the basic principles of [7] and [4]. A scale based on five levels of damage was developed, with the first level being sound grain and each of the other levels increasing in the proportion of damaged grain.

The five levels damage scale was defined in relation to the percentage of grain that showed evidence of insect damage. The range of values that were chosen to define each level was based on levels that farmers typically use to describe the relative use-value of a particular grain. For example, a sample of maize with $>85 \%$ damage would not be suitable for home consumption, but would be used as animal food. Maize with about $70 \%$ undamaged grains would be used for home consumption, depending on the financial status of the household, etc. (Tables 1- 4). The percentage categories are not the same for every grain, as discussed in more detail below. These scales are highly subjective, but it has been shown that the system is effective because it reflects the basis by which farmers usually assess the potential food or market value of their grain. 
Table 1 Damage classes for visual assessment of threshed maize

\begin{tabular}{|c|c|c|c|c|}
\hline Class & Composition & $\begin{array}{l}\% \text { weight } \\
\text { loss }\end{array}$ & Remarks on uses by farmers & $\begin{array}{l}\text { Sample } \\
\text { picture }\end{array}$ \\
\hline A & No damaged grain & 0 & $\begin{array}{l}\text { Suitable for home consumption, } \\
\text { sale to traders or used as seed } \\
\text { for next season }\end{array}$ & \\
\hline B & $\begin{array}{l}\text { A small percentage of } \\
\text { grains with slight } \\
\text { damage, about } 20 \% \\
\text { i.e., a few insect } \\
\text { holes }\end{array}$ & $1.1-3.3$ & $\begin{array}{l}\text { Suitable for home consumption, } \\
\text { sale to traders, or used as seed } \\
\text { for next season }\end{array}$ & \\
\hline $\mathrm{C}$ & $\begin{array}{l}\text { About } 50 \% \text { of the } \\
\text { grains damaged, with } \\
\text { insect holes, frass and } \\
\text { moth webs present }\end{array}$ & $4.5-7.8$ & $\begin{array}{l}\text { Damaged grains can be } \\
\text { removed and fed to animals. } \\
\text { Undamaged grain can be mixed } \\
\text { with A or B and consumed or } \\
\text { sold }\end{array}$ & \\
\hline $\mathrm{D}$ & $\begin{array}{l}\text { About } 70 \% \text { of the } \\
\text { grains damaged, with } \\
\text { insect holes, frass and } \\
\text { moth webs present. } \\
\text { Change in colour. }\end{array}$ & $8.2-15.0$ & $\begin{array}{l}\text { Depending on the financial } \\
\text { status of the household, the } \\
\text { undamaged grain can be } \\
\text { removed and the rest used for } \\
\text { home consumption, not good } \\
\text { for market }\end{array}$ & \\
\hline E & $\begin{array}{l}\text { About } 85 \% \text { of the } \\
\text { grains damaged, with } \\
\text { insect holes, frass and } \\
\text { moth webs present. } \\
\text { Change in colour }\end{array}$ & $17.1-26.3$ & $\begin{array}{l}\text { Not suitable for home } \\
\text { consumption, rather fed to fowl } \\
\text { and other domestic animals }\end{array}$ & \\
\hline
\end{tabular}


Table 2 Damage classes for visual assessment of threshed sorghum

\begin{tabular}{|c|c|c|c|c|}
\hline Class & Composition & $\begin{array}{l}\% \text { weight } \\
\text { loss }\end{array}$ & Remarks on uses by farmers & Sample picture \\
\hline $\mathrm{A}$ & No damaged grain & 0 & $\begin{array}{l}\text { Suitable for } \\
\text { consumption, sale to traders } \\
\text { or use as seed for next } \\
\text { season }\end{array}$ & \\
\hline B & $\begin{array}{l}\text { A small percentage of } \\
\text { grains with slight } \\
\text { damage about } 20 \% \\
\text { i.e., a few insect holes }\end{array}$ & $1.5-5.1$ & $\begin{array}{l}\text { Suitable for } \\
\text { consumption, sale to traders } \\
\text { or use as seed for next } \\
\text { season }\end{array}$ & \\
\hline $\mathrm{C}$ & $\begin{array}{l}\text { About } 40 \% \text { of the } \\
\text { grains damaged, with } \\
\text { insect holes, frass and } \\
\text { moth webs present }\end{array}$ & $6.7-11.4$ & $\begin{array}{l}\text { Damaged grains can be } \\
\text { removed and fed to animals. } \\
\text { Undamaged grain can be } \\
\text { mixed with A or B and } \\
\text { consumed or sold }\end{array}$ & \\
\hline $\mathrm{D}$ & $\begin{array}{l}\text { About } 60 \% \text { of the } \\
\text { grains damaged, with } \\
\text { insect holes, frass and } \\
\text { moth webs present }\end{array}$ & $13.2-22.2$ & $\begin{array}{l}\text { Depending on the financial } \\
\text { status of the household, } \\
\text { undamaged grains can be } \\
\text { removed and the rest can be } \\
\text { used for home consumption, } \\
\text { not good for sale, but with } \\
\text { careful grading can be sold } \\
\text { at low price }\end{array}$ & \\
\hline $\mathrm{E}$ & $\begin{array}{l}\text { About } 85 \% \text { of the } \\
\text { grains damaged with } \\
\text { insect holes, frass and } \\
\text { moth webs present }\end{array}$ & $24.7-40.2$ & $\begin{array}{l}\text { Not suitable for home } \\
\text { consumption, rather fed to } \\
\text { fowl and other domestic } \\
\text { animals }\end{array}$ & \\
\hline
\end{tabular}


Table 3 Damage classes for visual assessment of un-threshed sorghum

\begin{tabular}{|c|c|c|c|c|}
\hline Class & Description & $\begin{array}{l}\text { Average } \\
\text { weight loss }\end{array}$ & $\begin{array}{l}\text { Remarks on uses by } \\
\text { farmers }\end{array}$ & Sample picture \\
\hline $\mathrm{A}$ & No damaged grains & 0 & $\begin{array}{l}\text { Thresh and use for } \\
\text { home consumption, } \\
\text { sale to trader, or as } \\
\text { seed for next crop } \\
\text { season }\end{array}$ & \\
\hline B & $\begin{array}{l}\text { Very few damaged } \\
\text { grains }\end{array}$ & $1.6-3.5$ & $\begin{array}{l}\text { Thresh and use for } \\
\text { home consumption, } \\
\text { sale to trader, or as } \\
\text { seed for next crop } \\
\text { season }\end{array}$ & \\
\hline $\mathrm{C}$ & $\begin{array}{l}\text { Less than } 50 \% \text { grains } \\
\text { damaged and moth } \\
\text { webs present. Few } \\
\text { grains are destroyed } \\
\text { or missing }\end{array}$ & $4.7-10.1$ & $\begin{array}{l}\text { Threshed and sale to } \\
\text { traders at low price. } \\
\text { Can still be used for } \\
\text { home consumption or } \\
\text { sale to traders after the } \\
\text { damaged one are } \\
\text { removed }\end{array}$ & \\
\hline $\mathrm{D}$ & $\begin{array}{l}\text { More than } 50 \% \text { of } \\
\text { grains damaged or } \\
\text { contaminated with } \\
\text { moth webs and other } \\
\text { debris }\end{array}$ & $13.2-23.3$ & $\begin{array}{l}\text { Not good for home } \\
\text { consumption, remove } \\
\text { moth webbing and tie } \\
\text { into bales of about } 70- \\
80 \text { sorghum heads and } \\
\text { sale to livestock } \\
\text { owners }\end{array}$ & \\
\hline
\end{tabular}


Table 4 Damage classes for visual assessment for un-threshed millet

\begin{tabular}{|c|c|c|c|c|}
\hline Class & Description & $\begin{array}{l}\text { Average } \\
\text { weight loss }\end{array}$ & $\begin{array}{l}\text { Remarks by the } \\
\text { farmers }\end{array}$ & Sample picture \\
\hline A & No damaged grains & 0 & $\begin{array}{l}\text { Thresh and use for } \\
\text { home consumption or } \\
\text { sale to traders. Can be } \\
\text { used as seed for next } \\
\text { crop season }\end{array}$ & A \\
\hline B & $\begin{array}{l}\text { Very few grains } \\
\text { damaged about } 30 \% \\
\text { damaged grain }\end{array}$ & $3.4-10.4$ & $\begin{array}{l}\text { Thresh and use for } \\
\text { home consumption or } \\
\text { sale to traders. Can be } \\
\text { used as seed for next } \\
\text { crop season or sale }\end{array}$ & 20 \\
\hline $\mathrm{C}$ & $\begin{array}{l}50 \% \text { grains damaged } \\
\text { and moth webs } \\
\text { present. Few grains } \\
\text { are destroyed or } \\
\text { missing }\end{array}$ & $11.6-20$ & $\begin{array}{l}\text { Thresh and sale to } \\
\text { traders at low price. } \\
\text { With damaged one } \\
\text { removed can still be } \\
\text { used for home } \\
\text { consumption or sale }\end{array}$ & c \\
\hline $\mathrm{D}$ & $\begin{array}{l}\text { More than } 50 \% \text { of } \\
\text { grains damaged or } \\
\text { contaminated with } \\
\text { moth webs and other } \\
\text { debris }\end{array}$ & $22.4-28.4$ & $\begin{array}{l}\text { Not suitable for home } \\
\text { consumption, rather fed } \\
\text { to livestock }\end{array}$ & (4) \\
\hline
\end{tabular}

Once the percentage ranges for the five most significant levels of damage for each type of grain had been established, 'standardized' samples were produced representing the mean percentage damaged grains for each level by mixing the appropriate proportions of damaged and undamaged grains. Photographs of the standard samples were used to produce VDS charts for each type of grain representing the typical range of damaged experienced in farm stores for each type of grain, i.e., Class A-E (Table 1-4). The mean percent weight loss associated with each damage level of grain was determined by the 'count and weigh' method and added to the VDS charts as a second measure by which to score the class of a sample (Tables 1-4).

Similarly, the same visual damage method was followed for sorghum and millet heads (un-threshed). The visual damaged scale was prepared by initially collecting of samples from different farm stores and 
classified into four VDS of grade A-D as it occurred in the farmers stores, based on a sample of $\sim 10$ sorghum/millet heads for each damaged grade (Tables $1 \& 4$ ). However, weight loss for each VDS for these grains was determined by applying a modified version of 'count and weigh' method of assessing weight loss to each sorghum and millet head [7]. The calculated mean weight loss for each grade was used as a coefficient for the number of grain heads in that grade A-D and used as a formula (see below) for assessing visual loss in sorghum/millet heads.

Standard samples representing each damage class for each grain were carried in small plastic containers along with the VSD charts to the field to help farmers assess the status of their stored grain. The famers grain damaged and respective weight loss was assessed by collecting samples from farmers stores and each farmer was asked to compare the sample with standard samples or VDS chart that was most like their stored grain. The corresponding grain damage level in VDS chart and its weight loss was noted, and if the class score for farmers sample fell between two classes on the VDS chart, this was noted in the assessment record, and an intermediate class was declared (Example AB for intermediate class between Class A and B).

The percent weight loss for each farmer sample to be compared with the weight loss of the corresponding VDS samples was calculated by collecting a 100g subsample of the samples drawn from stores and then analyzed with the 'count and weigh' formula.

To assess the weight loss for the samples of sorghum and millet head, the number of grain heads corresponding to each class on the VDS was count and multiplied by the mean percent weight loss for that class in the equation below; these values were added together and divided by the total number of samples of grain heads to give overall estimate of weight loss.

Visual loss for sorghum $=\underline{0 \times \mathrm{NA}+3.1 \times \mathrm{NB}+5.4 \times \mathrm{NC}+19.2 \times \mathrm{ND}}$

NT

Visual loss for millet $=\underline{0 \times \mathrm{NA}+6.6 \times \mathrm{NB}+17.8 \times \mathrm{NC}+24.4 \times \mathrm{ND}}$

NT

Where:

Values shown refer to the mean percent weight loss for the class designated

NA-ND = number of grain heads in each class A-D

$\mathrm{NT}=$ total number of grain heads in each sample - usually 50

\subsection{Insect pest species identification}

As many insects as possible were extracted from the grain samples with a Brass Impact Test sieves (U.K.) (mesh sizes: $3.35 \mathrm{~mm}, 3.0 \mathrm{~mm}$ and $2.0 \mathrm{~mm}$ ). Insect samples were kept in sealed containers and taken to the laboratory at the College of Agriculture, Zuru, Kebbi, Nigeria for species identification using a light microscope (STM- 9T 16-x magnification). The insects were observed under the microscope for species identification, using the method of [8]

Samples of the pest moth $P$. interpunctella were obtained by hanging sticky Delta traps $(20 \times 21 \mathrm{~cm}$ base and $28 \times 15 \mathrm{~cm}$ sides, Agrisense, U.K.), baited with a pheromone lure (rubber septa) containing $0.1 \mathrm{mg}$ of P. interpunctella pheromone blend (Z9, E12 - 14:Ac, NRI) in grain storage structures. Each trap was suspended in a central position above stored grain. Pitfall traps baited with a general beetle's attractant (Agrisense, U.K.) were set in the stores, for two weeks to catch moths and beetles.

\section{Statistical Analysis}

Linear regression analysis was used to compare the correlation between the two methods of assessing weight loss (the VDS and Conventional methods). Analysis of variance (ANOVA) tests were performed using statistical software package R-statistic windows, version 2.10.0 (www.r-project.org) to analyse the data for grain weight loss, and chi-square was used for insect sampling data. A three way ANOVA analysis tested for the following factors that might have a significant effect on weight loss: region (north, central, south), storage type (granary, storeroom), grain type (threshed maize, threshed sorghum, unthreshed millet, unthreshed sorghum). The Tukey HSD test was used to compare the means of particular variables. Means are considered to be significantly different when $\mathrm{p} \leq 0.05$.

\section{Results}

\subsection{Comparison of VDS and Conventional method of assessing weight loss}

The weight loss measured by the count and weigh method and the VDS method were calculated for maize, sorghum and millet in order to compare their precision. The VDS method was highly correlated with the count and weigh method $\left(r^{2}=0.756\right)$, i.e., there was a positive linear relationship $(t=14.19, d f=147, p<0.001$, 
Fig. 1), which suggests that data obtained by the quicker VDS method is a reasonable alternative to the more time consuming conventional method.

\subsection{Insect species found in different stored grain}

In the grain samples used to assess weight loss, seven insect species were identified in sorghum, maize and millet (threshed and unthreshed data pooled for each grain type, and method of storage pooled for each grain type). Four species were coleopterans beetles (Tribolium castaneum, Rhyzopertha dominica, Sitophilus zeamais and Lasioderma serricorne), and the remaining three were lepidopteran moth species (Plodia interpunctella, Sitotroga cerealella and Corcyra cephalonica). In total, 3707 insects were collected, including T. castaneum, which was the most common species $(\mathrm{n}=969)$, with the highest mean number found in sorghum ( 11/store), followed in rank order by maize ( 9/store) and millet (4/store) (Fig. 2). The species found in the second highest number was $R$. dominica (547), which was found in the greatest abundance in sorghum ( $\sim 6 /$ store), followed by maize (5/store) and millet ( $\sim 3 /$ store). A total of $302 \mathrm{~S}$. zeamais were recorded, with the highest mean number in maize ( $4 /$ store), followed by sorghum $(\sim 2 /$ store $)$ and millet $(\sim 2)$. Lasioderma serricorne was the least found with similar number $(<2)$ in all the grain. For the Lepidoptera, $C$. cephalonica was found in greater numbers (663) than the other two species; $P$. interpunctella (581) and $S$. cerealella (584), with the highest mean number in sorghum (7/store), followed by maize (5/store) and millet ( 4). Amongst all the types of grain, millet had the lowest number of insect species. There was a statistically significant difference in the number of insect species found in the different types of grain $\left(\chi^{2}=230.62, \mathrm{df}=12, \mathrm{p}<0.003\right)$.

\subsection{Assessment of grain weight loss}

To estimate the percentage weight loss in different types of grain stored in different types of storage structures, grain samples were collected and assessed for weight loss using a conventional 'count and weigh' method. The ANOVA analysis showed that the following factors had a significant effect on weight loss: region $(\mathrm{F}=7.4861, \mathrm{df}=2, \mathrm{p}<0.001)$, storage type $(\mathrm{F}=16.2781, \mathrm{df}=1, \mathrm{p}<0.001)$ and grain type $(\mathrm{F}=18.7144, \mathrm{df}=3$, $\mathrm{p}<0.001)$. A significant difference in mean weight loss for grain type $(\mathrm{p}<0.001)$ was found only between threshed sorghum (13.12 \pm 1.01$)$ and all other grains, i.e. threshed maize $(10.36 \pm 1.01)$, unthreshed millet $(9.52 \pm 0.91)$ and unthreshed sorghum $(8.34 \pm 1.30)$, Tukey HSD. There was significantly greater amount of weight loss $(\mathrm{p}<0.001)$ in storerooms $(11.17 \pm 0.91)$ than granaries $(8.21 \pm 0.81)$. And irrespective of grain type, a significantly greater amount of weight loss $(\mathrm{p}<0.01)$ was found in the south $(11.87 \pm 1.03)$ than in the central $(9.20 \pm 0.92)$ and north $(9.18 \pm 0.95)$ regions, suggesting that the latter two regions experience better grain protection than the south region.

The results in Fig. 3 show the weight loss observed in the different grain stores (granary and room) of famers in Kebbi central. It indicates that storerooms provided the most consistent protection with similar levels of weight loss across all types of grain. There was an indication that grain stored in granaries provided better protection to unthreshed grain (millet and sorghum) with greatest weight loss in threshed sorghum. However, there was no significant effect of protection from weight loss in grain stored between storerooms and granaries and across all types of grain within the same storage structure (Tukey HSD; $p>0.05$ ).

The results in Fig. 4 show the weight loss observed in the different grain stores of famers in the Kebbi north. The results indicate that, both granaries and storerooms provided a similar level of protection with $>7 \%$ percentage weight loss across all types of grain, although $<7 \%$ was found in threshed maize stored in granaries and unthreshed sorghum stored in rooms. Threshed sorghum stored in both storerooms and granaries had the greatest weight loss $(>11 \%)$. However, there was no significant difference in weight loss between storerooms and granaries (Tukey HSD test; $\mathrm{p}>0.05$ ).

The results in Fig.5 show the weight loss observed in the different grain stores of famers in Kebbi south. There was a significant $(\mathrm{p}<0.05)$ effect of mean weight loss between threshed sorghum stored in storerooms $(>17 \%)$ and all other grain stored in storerooms and granaries $(<12 \%)$, Tukey HSD. 


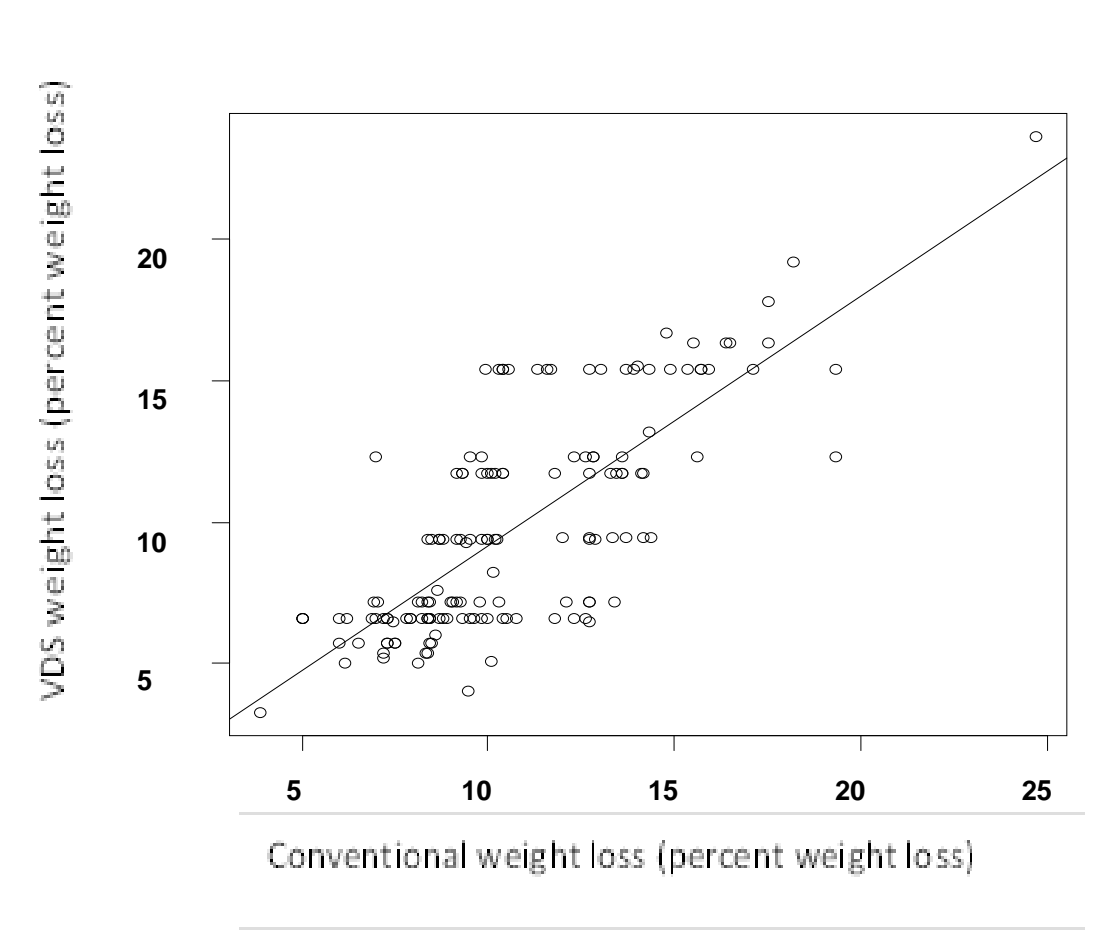

Figure 1 Correlation between the conventional (count and weigh) method and the visual assessment (VDS) method of assessing percent weight loss. The straight line indicates a linear correlation coefficient $(r=$ $0.756, \mathrm{~N}=150, \mathrm{p}<0.001)$.

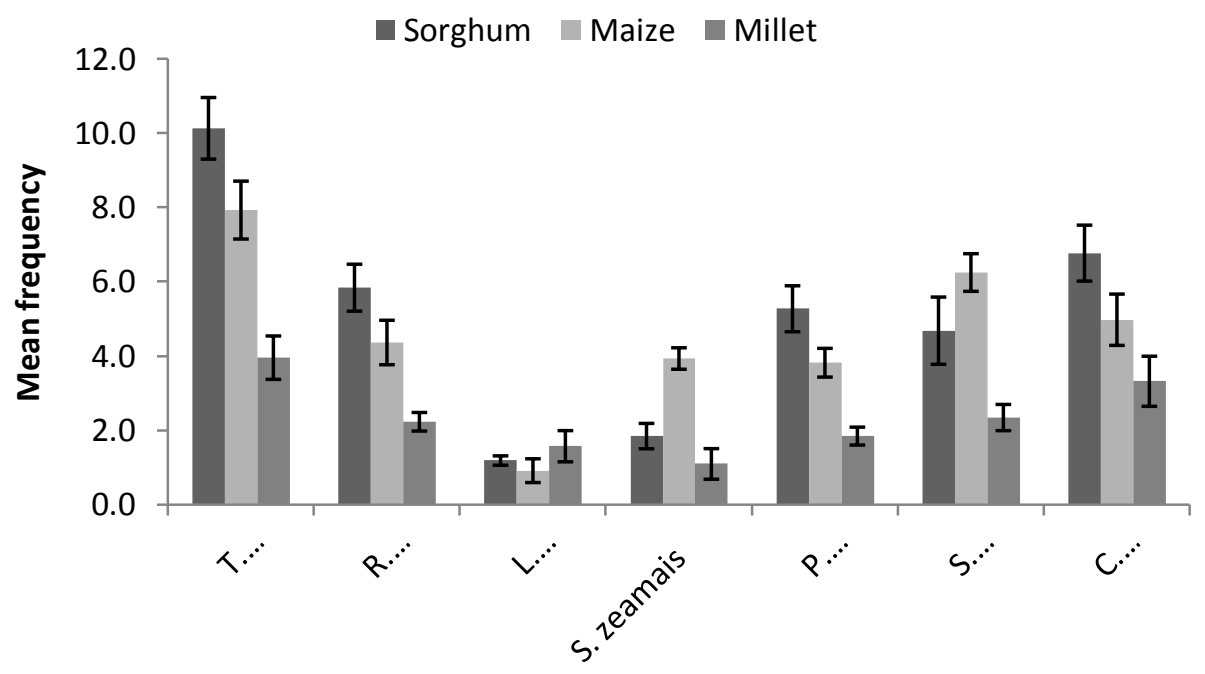

Figure 2 Mean frequency of insect species $( \pm \mathrm{SE})$ found in different types of grain that were stored by farmers in the survey area. The number of individual insects of each species found in each type of grain differed significantly ( $3 \times 7$ chi-square test of independence; $\chi^{2}=230.62, \mathrm{df}=12, \mathrm{p}<0.003$ ). 


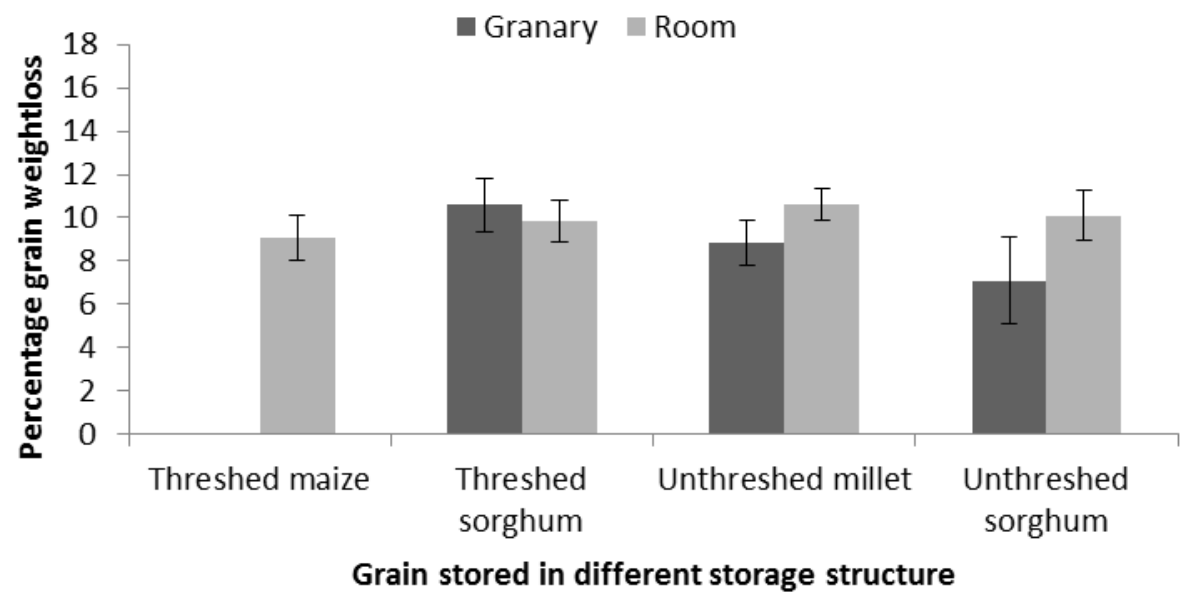

Figure 3 Mean percent weight loss $( \pm \mathrm{SE})$ observed in different types of grain stored using different storage structures for eight months in Kebbi central $(\mathbf{N}=\mathbf{5 0}$ stores). Standard error bars obtained from the analysis of variance residuals. ANOVA test indicates no significant difference $(p>0.05)$ in mean weight loss between grain and types of storage structures.

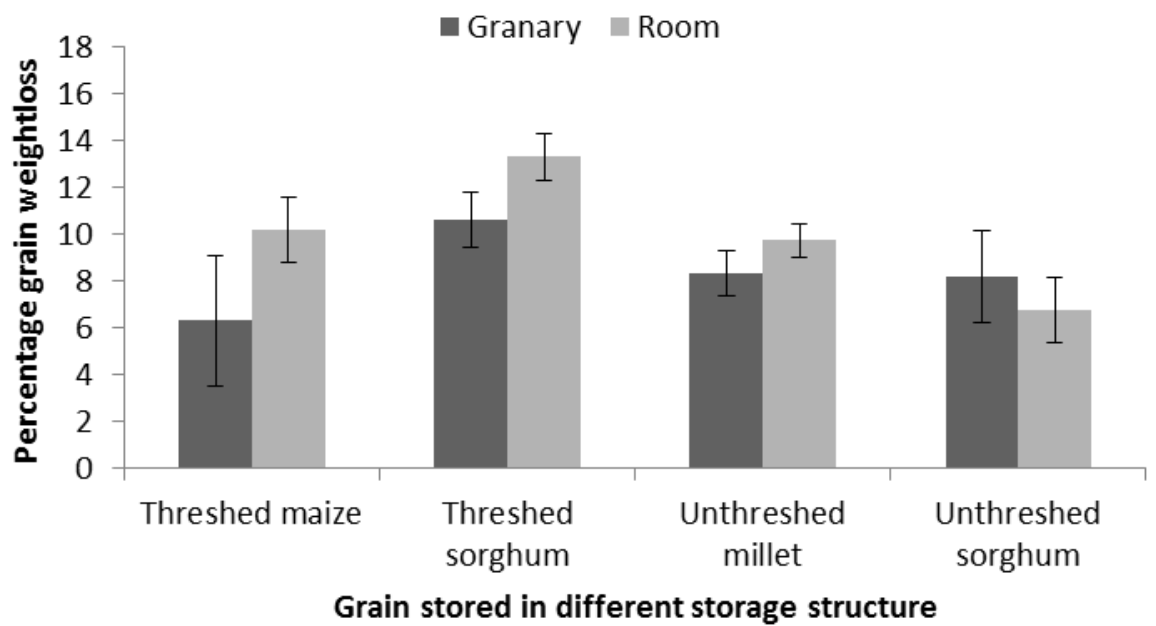

Figure 4 Mean percent weight loss $( \pm$ SE) observed in different types of grain stored using different storage structures for eight months in Kebbi north ( $N=\mathbf{5 0}$ stores). Standard error bars obtained from the analysis of variance residuals. ANOVA test indicates no significant difference $(p>0.05)$ found in the mean weight between grain and types of storage structures. 


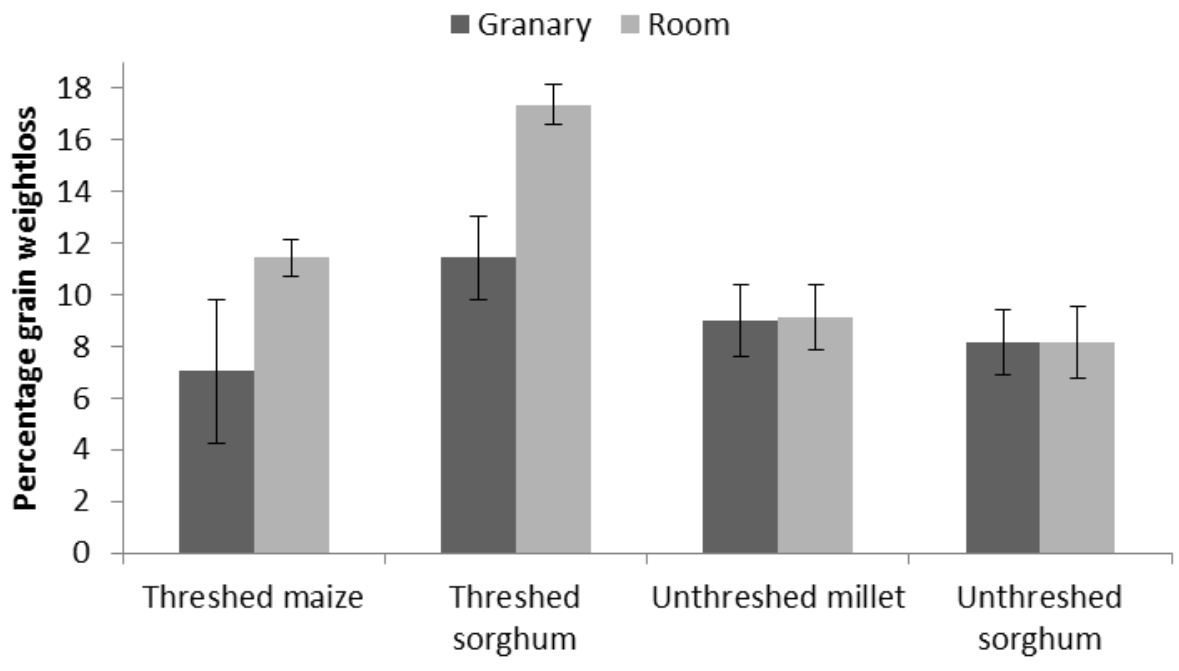

Grain stored in different storage structure

Figure 5 Mean percent weight loss $( \pm \mathrm{SE})$ observed in different types of grain stored using different storage structures for eight months in Kebbi south ( $\mathbf{N = 5 0}$ stores). Standard error bars obtained from the analysis of variance residuals. The only significant difference found in the mean weight loss was between threshed sorghum in rooms and all other grain in rooms and granaries unthreshed millet stored in bags and granaries (Tukey HSD; $\mathrm{p}<0.05$ ).

\section{Discussion}

Knowledge of storage conditions is a key to tackling storage problems. Accurate information about the species of insect causing the worst infestations and infestation levels in different types of farmers' grain stores can help in planning appropriate action at the right time [9]. The study presented in this here undertaken to gain a better understanding of farmers' grain storage situations and the impending associated problems. The aim was to develop a 'user-friendly' guide to identify the problems associated with grain storage and to help plan for future improvements. Kebbi state farmers are faced with serious problems associated with grain storage insect pests [10]. However, in the study area the insect pest species that cause the most important problems, the grain that is attacked most seriously and the factors that contribute to these problems have not been well established. In the research work presented in this study, the VDS weight loss method was developed to provide a rapid method of on-farm grain loss assessment and identification of insect pests most responsible for the damage. The VDS method had already been developed for un-threshed maize at the laboratory level [4], however, the results presented here demonstrate the application of VDS to obtain information from farmers about their perceptions of grain loss due to insect infestations in their locality, i.e., for the crops stored most commonly in their area and the insect pest most responsible for their stored crop losses.

The finding of this research indicates that the VDS method is comparable with conventional method of assessing weight loss and can be used as a rapid method of assessing the degree of damage to grain and proportional loss for sorghum, millet and threshed maize. More importantly can help farmers gain an understanding of the process and importance of grain damage which they can classify degree of grain damage and loss for themselves. Although the method might be open to some degree of error, as there may give an under-estimate of percent damage and weight loss for some insect species, particularly those for which the larvae bore into the grains [1]; [11], and therefore the damage to grains might not manifest during the time of assessments. However, as the name implies, VDS provides a practical and reasonably accurate assessment of grain based on a quick and simple visual observation.

The VDS method presented to farmers included the most common locally stored grains (sorghum, millet and maize), categorised into grades of damage from the 'no damage' to 'most damage', based on ranges of percent weight loss that had been determined previously as standards. The results and information obtained from famers' use of VDS indicates that it would be a useful way to involve farmers in assessing grain infestation and insect pest damage. For instance, during the survey, after a short argument among them, participating farmers were able to agree on the economic value and use of each grade in their locality. They determined that for the stored threshed maize to be marketed, it must have < 50\% damaged grains (5.7\% weight loss), for sorghum $<40 \%$ damaged grains ( $7.2 \%$ weigh loss) and for unthreshed millet $<50$ damaged grains $(17.8 \%$ weight 
loss). They also concluded that grain containing even higher percentages of damaged grains could be sold in the market if the damaged grain could be removed and mixed with sound grain. However, when the percentage damaged grains was about $70 \%$ for maize, $60 \%$ for sorghum and $>50 \%$ for millet farmers felt their only option was to remove damaged grains to be used as feed for the animals and use the undamaged grains for home consumption. The main problem with grain containing high levels of damaged grains is the high content of insect frass and debris. [8] Reported that grain that is heavily infested by insects usually has a strong smell of insect and debris, which discourages potential buyers. The market has a limited tolerance to the quality of grain it can accept, beyond which farmers have no option but to mix some of the high quality grain with the low quality grain to re-grade the grain overall, or if the grain is highly damaged, use it to feed animals, which is a great economic loss to the household. The information obtained from local farmers about their assessment of the potential use and value of each VDS Class in their locality was added to the VDS chart (Table 4.2 - 4.5), which will provide a useful reference to help all the farmers in the area check the status of their stored grain throughout the storage season and help them make decisions about how and when to improve their grain storage practices.

In Kebbi, the study area, information on the most damaging insect species' and the type of grain most damaged is not well established. Therefore, a part of this study was carried out to obtain baseline data on the insect pest species and associated weight loss they cause in the different storage structures used by farmers.

The most commonly found insect was $T$. castaneum, followed by $R$. dominica, C. cephalonica, $P$. interpunctella, S. cerealella and L. serricorne. It is not surprising that sorghum suffered the most weight loss of the crops assessed, as it had the highest number of pest species, and the highest number of insects of each species, mainly $T$. castaneum, $R$. dominica and $C$. cephalonica. These findings are consistent with [12] and [13] reports that the level of damage to stored grain due to insects depends on the type and population size of pests in the grain, as well as the influence of environmental factors that support their development.

The analysis of grain weight loss due to insect damage for the different types of grain stored in the different regions indicates that sorghum stored in threshed state had more weight loss than sorghum stored in unthreshed form. The effect of weight loss varies in threshed sorghum stored in rooms in the south and all other types of grain stored in both granaries and rooms in all regions. This suggests preferences of insects to certain types of grain, storage structure and region than the others. Granary is a storage facility known to be used by many small-holder farmers in many parts of Africa, including Nigeria [14] and [15]. However, in this research it was found that many farmers store their grain in storerooms associated with the main dwelling, either in bags or just loose in the storerooms. Considering the nature and the type of the room used by farmers for grain storage in the surveyed area, it is not surprising that grain stored in loose or in bags in storerooms had more weight loss than grain stored in granaries. Some granaries that are common in the study area are sealed, with only one access on the roof or a small window on the side. This is contrary to the conditions of storerooms found in the surveyed area; they have many openings, such as small doors as an entrance to the room and sometimes windows. Items other than grain are often stored alongside the grain, which increases the movement of people. Hence, there is a greater chance of grain loss due to insects, moisture and pathogens, which can move more easily in and out of this type of store compared to local granaries.

\section{Conclusion}

This part of the survey was intended to be a quick study to get an indication of which type of grain in which region was most in need of improvements to insect pest control. Therefore, despite the variability in the data for weight loss assessment, it appears that sorghum attacked most by the storage insects mainly $T$. castaneum in the southern region. This insect causes the most damage, especially when sorghum is stored in storerooms rather than in granaries. For farmers to enjoy the market value of their stored sorghum, it must be maintained within the accepted market quality. Based on the analysis of damage levels and weight loss done in this phase of the research most of the grain observed was damaged above the level accepted for sale in the market. Hence, this highlights the area that requires intervention; low-income farmers, who cannot maintain conditions required to produce good quality stored grain, due to their financial status or access to good storage management facilities, are more liable to produce and live off of food of low nutrient value, thus are most in need of help with a better insects' control.

\section{References}

[1] Gwinner, J., Harnisch, R. and Mück, O. Manual on the prevention of post-harvest grain losses, post-harvest project, Pickhuben 4, D-2000 Hambung, 1990.

[2] Mendalis, E., Abdeta, C., Tesfaye, A., Shumeta, Z. and Jifar, H. Farmer's perceptions and management practices of insect pest on stored sorghum in Ethiopia. Crop Protection 26, 2007 1817-1825.

[3] Anonymous.. Post-harvest food losses in developing countries. Board on Science and Technology for International development Commission on International Relations, National Resources Council. National Academy of Science Washington DC. 1978, 206pp.

[4] Compton, J.A.F. and Sherington, J. Rapid assessment methods for stored maize cobs: weight losses due to insect pests. Journal of stored products Research 35, 1999. 77-87. 
[5] Hodges, R.J.. Post-harvest Team: Preparatory activities for a mahangu storage management survey and loss assessment baseline. National Agricultural Support Services Programs (NASSP) In Namibia, 2005.

[6] Adams, J.M. and Schulten, G.G.M. Losses caused by insect mites and microorganisms. In: Harris, K.L. and Lindblad. Post-harvest grain loss assessment methods: a manual of methods for the evaluation of post-harvest losses. (England: American Association of Cereal Chemist, 1978) 83-99.

[7] Compton, J.A.F., Floyd, S., Ofosu, A. and Agbo, B. The modified count and weight method: an improve procedure for assessing weight loss in stored maize cobs. Journal of Stored Product Research 34 (4), 1998, 277-285.

[8] Dobie, P., Haines, C.P., Hodges, R.J., Prevett, P.F. and Rees, D. P. . Insects and Arachnids of tropical stored products: Their biology and identification (training manual). (Natural Resources Institute, Chatham Maritime, UK, 1991) P.232.

[9] Loewer, O.J., Bridges, T.C. and Bucklin, R.A. On-farm Drying and storage system. (United State of America: American Society of Agricultural Engineering, 1994) 560pp.

[10] KARDA (Kebbi Agriculture and Rural Development Authority). Agricultural potentials of Kebbi State. KARDA along Kalgo road, Birnin Kebbi, Kebbi State, Nigeria, 2004.

[11] Cronholm, G., Knutson, A., Parker, R., Teettes, G. and Pendleton, B. Managing insect and Mite pests of Texas sorghum. Texas Agric. Exp. Stat. Bull., B-1220. 1998, 26pp.

[12] FAO (Food and Agriculture Organization). Introduction to general taxonomy and biology/ ecology of stored product insect pests. In: Semple, R.L., Hicks, P.A., Lozare, J.V. and Castermans, A. (Eds.). Towards integrated commodity and pest management in grain storage. Training manual for application in humid tropical storage system. FAO Cooperate document repository, 1992. http://www.fao.org/docrep.

[13] Odogola, W.R. Post-harvest management and storage of food legumes: Technical system for Agriculture. (Zimbabwe: AGROTECC . 1994) 59pp.

[14] Udoh , J.M., Cardwell, K.F. and Ikotun, T. Storage structures and aflatoxin content of maize in five agro-ecological zones of Nigeria. Journal of Stored Product Research 36, 2000, 187-201.

[15] Bett, C. and Nguyo, R. Post-harvest storage practices and techniques used by farmers in Semi-arid Eastern and Central Kenya. African Crop Science Conference Proceedings 8, 2007. 1023-1227. 